\title{
Impact of weather and climate variation on Hoopoe reproductive ecology and population growth
}

\author{
Raphaël Arlettaz $\cdot$ Michael Schaad . \\ Thomas S. Reichlin • Michael Schaub
}

Received: 17 November 2009/Revised: 16 March 2010/Accepted: 24 March 2010/Published online: 21 April 2010

(C) Dt. Ornithologen-Gesellschaft e.V. 2010

\begin{abstract}
Preserving peripheral populations is a key conservation issue because of the adaptive potential to environmental change they provide for the species as a whole. Yet, peripheral populations are often small and isolated, i.e. more vulnerable to stochastic events and prone to extinction. We studied a peripheral population of Hoopoe (Uрира epops), a rare insectivorous farmland bird, in the Swiss Alps. We first investigated the effect of weather variation on food provisioning to chicks by Hoopoe parents. Second, while accounting for density-dependence, we tested the extent to which breeding success is governed by weather circumstances and assessed the possible consequences of climate variation on population growth. Provisioning rate and provisioned prey biomass were negatively affected by adverse weather (cool, rainy days), were higher in males and also increased with brood size. Much smaller proportions of molecrickets (Gryllotalpa gryllotalpa; the
\end{abstract}

M. Schaad and T. S. Reichlin contributed equally to the work.

Communicated by P. H. Becker.

R. Arlettaz ( $\square) \cdot$ M. Schaad · T. S. Reichlin · M. Schaub Division of Conservation Biology,

Institute of Ecology and Evolution, University of Bern,

Baltzerstrasse 6, 3012 Bern, Switzerland

e-mail: raphael.arlettaz@iee.unibe.ch

R. Arlettaz

Valais Field Station, Swiss Ornithological Institute,

Nature Centre, 3970 Salgesch, Switzerland

R. Arlettaz

The Ecology Centre, University of Queensland,

St Lucia, QLD 4072, Australia

T. S. Reichlin · M. Schaub

Swiss Ornithological Institute, 6204 Sempach, Switzerland most profitable prey locally, constituting 93\% of chicks' food biomass) were provisioned on days with adverse weather, irrespective of brood size. Rainfall prior to hatching and during the first days of chick life had a negative impact on their survival, and there was a positive effect of temperature on chick survival just before fledging. Reproductive output was negatively affected by precipitation during the hatching period, but was enhanced by warm temperature just before hatching and in the last days before fledging. Our model showed that the variable reproductive output has a strong impact on the population growth: a succession of adverse, rainy springs would cause a rapid decline of the population. This case study confirms that conservation efforts may be obliterated if risks linked to increasing climate variability are not properly accounted for in the management of small peripheral populations.

Keywords Bird conservation · Food provisioning · Insectivorous birds - Reproduction versus climate variation · Trophic ecology

\section{Introduction}

Species conservation has long focused on habitat protection and restoration. New globally emerging threats, such as climate change, may obliterate habitat management efforts, in particular when a species' demography is sensitive to environmental stochasticity (Sala et al. 2000; Parmesan and Yohe 2003; Thomas et al. 2004). Wide-scale range shifts of species have been predicted in the long term due to progressive changes in temperature and precipitation regimes (e.g. Huntley et al. 2008). Under a scenario of rising climate variability (Easterling et al. 2000), however, peripheral populations (here defined as geographically and 
altitudinally marginal) may sooner suffer from environmental stochasticity. This is because ecological conditions prevailing at range periphery are naturally suboptimal (Lawton 1993). In addition, peripheral populations are often small and isolated, which theoretically renders them more susceptible to gradual environmental change, demographic stochasticity and catastrophic events (Nathan et al. 1996; Nantel and Gagnon 1999; Antonovics et al. 2006). The contention that peripheral populations are more prone to extinction has, however, been refuted by some researchers (Lomolino and Channell 1995; Channell and Lomolino 2000). Irrespective of this, the strength of decline or the probability of extinction of the species as a whole could be further exacerbated by the loss of possible specific adaptations to local conditions (Hoffmann and Blows 1994). Peripheral populations could thus potentially buffer against loss of a species' overall evolutionary aptitude in the face of a rapidly changing environment (Reznick et al. 1997; Hendry and Kinnison 1999; Crandall et al. 2000). They should therefore be a primary focus of conservation biology (Lesica and Allendorf 1995; CasselLundhagen et al. 2009; Gibson et al. 2009).

One of the most important demographic parameters is recruitment (Sæther and Bakke 2000), which, all else being equal, depends primarily on the number of offspring produced (Crick et al. 1993; Newton 1998). This is especially true in short-lived species. In several such species, the number of offspring depends to a large extent upon seasonal weather circumstances during reproduction (e.g. Siikamäki 1996; Veistola et al. 1997; Newton 1998; Rodríguez and Bustamante 2003; Geiser et al. 2008). Weather often impacts food availability, but, due to its strong stochasticity, food availability remains mostly unpredictable for individuals engaging in reproduction (Cucco and Malacarne 1996a, b; Mills et al. 2008). Food availability depends firstly on fluctuations in prey populations (either seasonal or inter-annual), secondly on prey detectability (partly determined by the prey activity pattern), and thirdly on prey accessibility. Although the latter may be hampered by variations in foraging habitat structure (Schaub 1996), weather affects all three factors above. Species that feed on insects are primarily concerned since poikilothermic organisms reduce their overall activity in bad weather conditions, thereby becoming unavailable to predators (Taylor 1963; Avery and Krebs 1984; Cucco and Malacarne 1996a; Veistola et al. 1997; Arlettaz et al. 2000, 2001). Birds that have population strongholds in lower latitudes would thus be more likely to suffer from weather and climate variation when occurring at range margin in cooler climates (e.g. in the north or close to their upper altitudinal limit), although this remains controversial (Sagarin and Gaines 2002). For ground-feeding insectivorous birds, very few studies have documented the impact of weather conditions on both food provisioning performance to chicks by parents, reproductive output and population growth (Radford et al. 2001; Geiser et al. 2008).

The Hoopoe Upupa epops has become rare in Central and Western Europe (Hustings 1997). It has been suggested that Hoopoes are particularly sensitive to climatic conditions, in particular precipitation during reproduction (Glutz von Blotzheim and Bauer 1980; Cramp 1985; Rehsteiner 1996). This may explain why western European populations, where rainfall tends to be high due to exposure to depressions coming from the west, seem to fluctuate more than Mediterranean and eastern populations (Bussmann 1950; Cramp 1985; Rehsteiner 1996). Yet, the mechanism by which weather and climatic conditions affect population dynamics and determine long-term modification of distribution range in this species remains unknown (Laiolo et al. 1998; Radford and Du Plessis 2003). This study aims to unravel that mechanism.

The Hoopoe is red-listed in Switzerland and is among the 50 bird species for which conservation action plans are currently under development (Keller et al. 2001). In the 1990s, only a few dozens of breeding pairs remained, mostly on the plain of the upper Rhône valley, where a small population has been monitored since 1979 (Arlettaz 1984; Arlettaz et al. 2000). The Valais Hoopoe population is both isolated and altitudinally peripheral as the plain of the upper Rhône is flanked in the north and in the south by two major mountain ranges culminating at more than $4,000 \mathrm{~m}$. There is, therefore, not only a discontinuity to the next populations in Italy and France (situated hundreds of kilometres away in the south), but also a very continental climate with frequent cold spells during the breeding season due to the proximity of the mountains. As the Valais Hoopoes were continuously declining, a tailored conservation programme was launched in 1998 (Arlettaz et al. 2000), based on conservation recommendations drawn by Fournier and Arlettaz (2001). The implementation of these measures has led to a progressive recovery of the population (from ca. 20 to more than 100 broods a year), which, however, remains small (Arlettaz et al. submitted).

In this study, we first looked at the impact of weather variation on the efficacy of food provisioning to chicks by parents. Second, we attempted to test to which extent reproductive performance is affected by weather. We had to account for possible effects of density because our population has recently been expanding. Finally, we assessed the potential impact of weather variation on Hoopoe population dynamics. This information will be crucial not only for the long-term conservation management of the Valais Hoopoes, but also to predict species' response to future climate change and weather variation. 


\section{Methods}

The study was carried out in 2000-2006 on the plain of the Upper Rhône Valley (Central Valais, south-western Swiss Alps; $\left.46^{\circ} 2^{\prime} \mathrm{N}, 07^{\circ} 4^{\prime} \mathrm{E}\right)$. The plain $(460-520 \mathrm{~m}$ altitude) is primarily devoted to industrial farming, in particular dense dwarf fruit tree plantations, vegetables and vineyards. Our study population uses nestboxes almost exclusively as nest sites. Nestboxes $(n \sim 700)$ were checked every second week during the breeding season, from mid-April to late July. Those containing broods were additionally checked every second to third day for close tracking of the course of breeding.

\section{Food provisioned to chicks}

In 2001, 26 broods were filmed for three entire days each during the chick feeding period-which lasts 26-29 days in the Hoopoe (Cramp 1985) - in order to collect data on nestling diet and parent foraging ecology. The first filming (brood stage I) took place when chicks were 11-15 days old, the second (brood stage II) when they were 16-20 days old, and the third (brood stage III) at 21-25 days. We did not film at an earlier age because the mother covers the chicks until they start to thermoregulate by themselves and thus does not deliver food to the young. The video systems consisted of a camera (CCD-7012P; Videotronic, Neumünster, Germany) coupled with a time-lapse video recorder (SRT 7168P; Sanyo, Osaka, Japan); electricity was supplied by a generator. Video-monitoring lasted from approximately 0600-2100 hours. The chicks were counted at the beginning and at the end of a filming session. Adult Hoopoes were mist-netted and ring-marked at nesting sites when chicks were 5-10 days old. Sex-specific codes were drawn with markers on parents' head feathers; clearly visible on the video-tapes, this marking enabled gender recognition so as to assess sex-specific provisioning activity.

For each feeding event, the following variables were noted from video sequences: time, sex of provisioning adult, prey type (we distinguished molecrickets Gryllotalpa gryllotalpa, caterpillars, and other prey) and item size. Dry biomasses were estimated based on Arlettaz and Perrin (1995). For molecrickets, we recognized three size classes, including larvae ( 2 sizes, with an estimated average biomass of 0.36 and $0.46 \mathrm{~g}$ per item, respectively) and imago $(0.68 \mathrm{~g})$. Average dry weight of caterpillars and other prey were set to an average of $0.08 \mathrm{~g}$ (Arlettaz and Perrin 1995). We calculated feeding frequency and estimated provisioned biomass per hour. Hoopoes are single prey loaders (they provision only one prey item at a time), which facilitated prey identification.

From a principal component analysis (PCA) run with four weather variables (sunshine duration per day, mean daily temperature, daily amount of rainfall, and mean daily relative humidity, all recorded in the core of the study area, at Sion meteorological station; $46^{\circ} 2^{\prime} \mathrm{N}, 07^{\circ} 4^{\prime} \mathrm{E}$; on-line database MeteoSwiss), we obtained a proxy of daily weather conditions throughout the season $(n=50$ days), which consisted of the first factor of the PCA (explaining $63 \%$ of the overall model variance). The first factor correlated positively with temperature $(r=0.60)$ and sunshine duration $(r=0.90)$ and negatively with rainfall $(r=-0.70)$ and humidity $(r=-0.93)$. Thus, positive values correspond to "nice" days (warm and dry), whilst negative values describe "bad" days (cool and rainy).

Using structurally equal statistical approaches with the same independent variables, we analysed feeding rate (number of parental food provisioning events per hour, assuming Gaussian distributed errors), biomass delivered to nestlings per hour (assuming Gaussian distributed errors) and the proportion of molecrickets among all delivered food items (assuming binomially distributed errors) by applying generalized linear mixed models (lmer, R Development Core Team 2008). Brood identity was considered a random factor. The fixed factors were sex, brood stage, brood size and weather. To test whether the potential impacts of sex and weather changed with brood stages, we also included the two-way interactions sex $\times$ brood stage and weather $\times$ brood stage. We fitted 24 candidate models (all possible combinations of fixed effects) and ranked them according to their support by the data with the Akaike Information criteria (AICc; Burnham and Anderson 2002).

\section{Reproductive success versus weather variation}

Data on reproductive output (number of fledglings per brood) and nestling survival (percentage of hatched young that fledged) from 2000 to 2006 were used to test whether reproductive success for each single brood was related to variation in weather conditions ( $n=514$ broods). Only broods with at least one egg hatching were considered in the analysis.

As weather variables we used daily mean ambient temperature and daily amount of rainfall, recorded by the meteorological station in Sion. Rain $(r)$ and temperature $(t)$ values were averaged over 5-day periods (pentades, $p$ ), such that the hatching day for each single brood was the last day of pentade 0 (i.e. $r_{0}$ corresponds to the average rainfall of the pentade $p_{0}$ starting on the fourth day before hatching and ending with the day of hatching, being day 0 ). Average values were also calculated for the three subsequent pentades, starting on the first day after hatching and ending 15 days later $\left(r_{1}=\right.$ average of days $1-5$ after hatching, $r_{2}=$ average of days 6-10 after hatching, $r_{3}=$ average of days 11-15 after hatching; similar calculations were made for temperature, $t_{0}$ through to $t_{3}$ ). 
We used an information-theoretic approach (Burnham and Anderson 2002) for model ranking and to identify whether temperature and rain impact on breeding performance, and if so which pentade(s), in terms of temperature and rain, play(s) the most crucial role. We applied generalised linear mixed models analysed in the program $\mathrm{R}$ with library lmer (R Development Core Team 2008). With an abbreviated model selection procedure (to reduce model complexity) and according to the $\triangle \mathrm{AICc}$, we defined the best model describing the influence of rain and temperature on the reproductive success of our local Hoopoe population (Fig. 1). Rain and temperature values, as well as breeding density (which increased over time) and hatching date, were treated as fixed effects, whereas the location of the brood (nestbox site) was treated as a random effect in order to avoid pseudoreplication. Hatching date was only included in the models for reproductive output, but not for the survival of the hatchlings as we assumed that the latter is not influenced by the time of breeding. For the calculation of reproductive output, the data were assumed to reflect a Poisson distribution, while for the nestling survival, the response variable was assumed binomial.

\section{Population growth}

To assess the potential importance of the impact of weather at the population level induced by variable reproductive output, we calculated the population growth rate $(\lambda)$ using a simple female-based population model. In this model, we assumed adult survival $\left(S_{\text {ad }}\right)$ to be 0.4 , first year survival $\left(S_{1}\right)$ to be 0.18 , the proportion of females conducting a second brood $\left(p_{2}\right)$ to be 0.4 and an even sex ratio. The values of $S_{\text {ad }}$ and $p_{2}$ stem from our population (Reichlin et al., in review), $S_{1}$ was chosen in such a way that the population growth is $\sim 1$. We further assumed that the population is closed geographically. The growth rate of the population is then $\lambda=S_{\text {ad }}+S_{1}\left(1+p_{2}\right) F / 2$, where $F$ is the reproductive output of a brood. We used the predictions of $F$ for the various weather variables as obtained from the analyses above.

\section{Results}

\section{Nestling diet}

The video footage comprised 78 tapes ( $n=26$ broods, with 3 days of filming each; $1,172 \mathrm{~h}$ ). In total, 5,454 prey items were recorded; they consisted of $59.3 \%$ molecrickets, $20.3 \%$ lepidoptera larvae, and $4.9 \%$ other prey (Aranaeidea, Coleoptera, Formicidae, Diptera larvae-mostly Tipulidae); $15.5 \%$ items could not be identified (Fig. 2). From a dry biomass point of view (total biomass $=2,226.4 \mathrm{~g}$ ), molecrickets were estimated to make up $93 \%$ of the overall
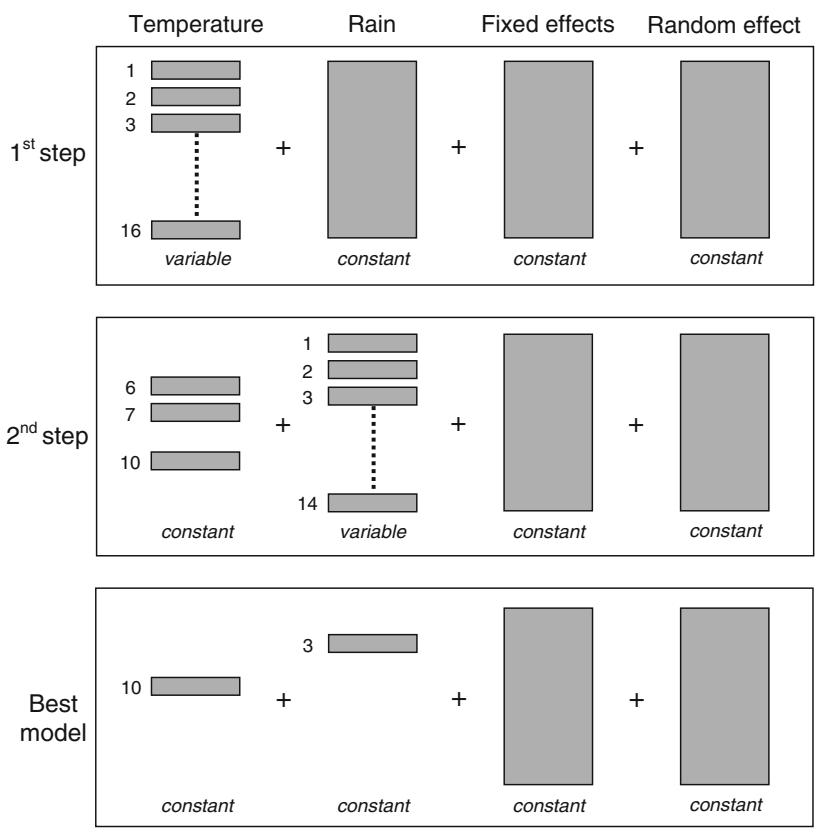

Fig. 1 Overview of the abbreviated modelling procedure adopted here to reduce model complexity for the analysis of the relationships between reproductive success of Hoopoes (Upupa epops) and weather factors. First step: only the four temperature variables $\left(t_{0-3}\right.$, see "Methods" for nomenclature) were varied in all possible combinations (resulting in 16 different models, including the null model), with rain put in the model as «full model» $\left(r_{0-3}\right)$ and the other effects held constant [fixed effects: breeding density and hatching date (the latter only in reproductive output modelling); random effect: breeding site (nestbox)]. Second step: Based on AICc (threshold for further selection $\triangle \mathrm{AICc}<2$ ), the best models with varying temperature were chosen and held constant, whilst the rain parameters $\left(r_{0-3}\right)$ were sequentially added to the best models from step one, also in all possible variations (14 different models per fixed temperature variable). Again, other effects were held constant. Third step: from this abbreviated model selection procedure followed the best models that described the influence of weather on reproductive success. It did not matter to the outcome for the best model whether to first vary the temperature parameters, or rain parameters

diet, lepidoptera larvae and unidentified prey $3 \%$ each, and other prey items about $1 \%$ (Fig. 2).

Food provisioning by parents

Variation in the hourly feeding rate (mean \pm SE) could be explained by sex, weather and brood size (two best models), whilst brood stages were retained only in the third best model; moreover, their confidence intervals largely overlapped with 0 (Table 1a). Hourly feeding rates increased with brood size (by $0.32 \pm 0.12$ feedings/h per nestling) and with the weather factor (by $0.17 \pm 0.09$ feedings/h per PCA score); it was also higher in males $(2.69 \pm 0.23)$ than in females (1.84 \pm 0.20 ; Fig. 3$)$.

The prey biomass delivered to chicks was affected by the same variables as feeding rate (Table $1 \mathrm{~b}$ ). It increased 


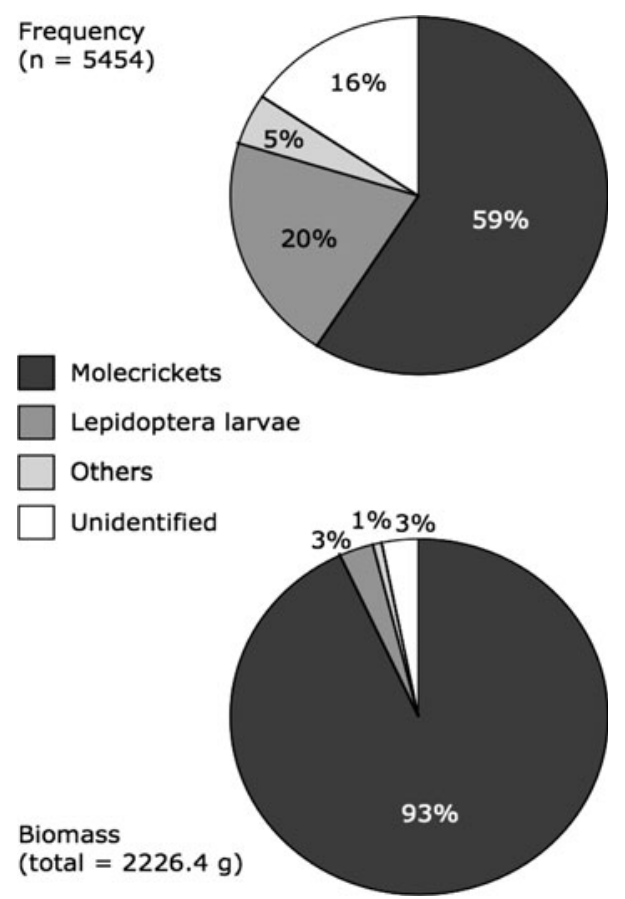

Fig. 2 Frequency ( $n$ ) and biomass (g) of prey categories entering the diet of Hoopoe chicks

with brood size (by $0.21 \pm 0.03 \mathrm{~g} / \mathrm{h}$ per nestling) and favourable weather conditions (by $0.12 \pm 0.04 \mathrm{~g} / \mathrm{h}$ per PCA score; Fig. 4). Males delivered, on average ( \pm SE), more biomass per hour $(1.23 \pm 0.08 \mathrm{~g})$ than females $(0.68 \pm 0.08 \mathrm{~g} ;$ Fig. 3$)$. Again, there was still some uncertainty regarding an effect of brood stage (Table $1 b$ ). The interaction terms were not important, indicating that the relationships between delivered biomass and sex, and between biomass and weather remained the same irrespective of brood stage (Figs. 3, 4).

The proportion of molecrickets among all delivered food items differed between sexes and brood stages (Table 1c). The proportion was also affected by weather and by brood size (Table 1). Males delivered a higher proportion of molecrickets $(0.90 \pm 0.04$ of the prey items per hour) than females $(0.82 \pm 0.06$ of items $/ \mathrm{h})$. The proportion of molecrickets was highest at the first brood stage $(0.90 \pm 0.04)$ and decreased slightly thereafter (stage II: $0.85 \pm 0.04$; stage III: $0.84 \pm 0.06$; Fig. 3 ). Finally, the proportion of molecrickets in chick food increased when good weather conditions prevailed (slope on the logit scale: $0.21 \pm 0.03$ ) and with increasing brood size (slope on the logit scale: $0.29 \pm 0.09$ ).

Reproductive success versus weather conditions

Mean annual reproductive output (2000-2006) varied between 3.97 and 5.51 fledglings per brood (overall mean \pm SE: $4.71 \pm 2.31$ ), and mean nestling survival between 72.3 and $86.6 \%(79.3 \% \pm 0.31$; only broods with at least one hatchling were considered, $n=514)$. Concerning reproductive output, $r_{0}$ and $r_{1}$ (rainfall in pentads 0 and 1 ) and $t_{0}$ and $t_{3}$ (temperature in pentads 0 and 3 ) were included in the best model (Table 2). The number of fledglings was positively associated with temperature, while rainfall exerted a negative influence on this parameter. It was also negatively associated with breeding density and hatching date (Fig. 5 bottom). Nestling survival was negatively affected by $r_{0}$ and $r_{1}$, whilst $t_{3}$ had a positive effect and $t_{2}$ a negative one (Table 3 ).

\section{Population growth}

The predicted minimum and maximum values of the reproductive output for the weather variables $t_{0}, t_{3}, r_{0}$ and $r_{1}$ (Fig. 5) were used to calculate the potential population growth rate under this range of weather conditions. The ranges of the population growth rates were large $\left(t_{0}: 0.89\right.$ $\left.1.02 ; t_{3}: 0.85-1.07 ; r_{0}: 1.01-0.79 ; r_{1}: 0.99-0.83\right)$ indicating that weather variation can potentially have a strong impact on Hoopoe population growth, even if only reproductive output were affected.

\section{Discussion}

This study supports the hypothesis that an important component of Hoopoe population dynamics is sensitive to weather variation. It further establishes the mechanism involved in the demographic process: cool, rainy days actually affect the efficiency of food provisioning by parents to chicks, which lowers reproductive success. Given a rapid generation turnover in this species (Reichlin et al., in review), Hoopoe population dynamics appears to be driven principally by recruitment and immigration. A sustained drop in productivity, as could be experienced under a succession of rainy springs would lead to population declines within short time. Although climate scenarios all predict a greater weather variability in the future (e.g. Easterling et al. 2000), detailed projections about temperature and rainfall regimes remain scarce for the Alps. Most studies predict an increase in ambient temperature, but predictions for precipitation remain uncertain. Wanner et al. (1997) predict an increase in rainfall, especially in spring, Horton et al. (2006) a general annual decrease, but without any clear tendency for spring. At this stage, it is thus difficult to foresee how the Valais population will respond to climate variation in the future.

Adverse weather conditions resulted in reduced feeding activity, i.e. a drop in the total biomass of provisioned prey caused primarily by a diminished proportion in the diet of 
Table 1 Influence of sex, brood stage and brood size of Hoopoes (Upupa epops) and weather, as well as interactions of brood stage with sex and weather, a on feeding rate $(n / \mathrm{h})$, b biomass delivered per hour ( $\mathrm{g}$ ) and $\mathbf{c}$ proportion of molecrickets in chick diet, evaluated by a model selection procedure (24 candidate models; see Fig. 1)

\begin{tabular}{|c|c|c|c|c|c|c|}
\hline & \multicolumn{2}{|c|}{ Best model } & \multicolumn{2}{|c|}{ 2nd best model } & \multicolumn{2}{|c|}{ 3rd best model } \\
\hline & Estimate & SE & Estimate & SE & Estimate & SE \\
\hline \multicolumn{7}{|l|}{ Feeding rate } \\
\hline \multicolumn{7}{|l|}{ Model selection criteria } \\
\hline$\triangle \mathrm{AICc}$ & 0.00 & - & 1.18 & - & 2.87 & - \\
\hline $\mathrm{AICcw}$ & 0.44 & - & 0.24 & - & 0.10 & - \\
\hline Deviance & 599.59 & - & 602.95 & - & 598.03 & - \\
\hline \multicolumn{7}{|l|}{ Effects } \\
\hline Intercept & 1.219 & 0.607 & 1.252 & 0.598 & 1.289 & 0.672 \\
\hline $\operatorname{Sex}^{\mathrm{a}}$ & -0.875 & 0.261 & -0.875 & 0.266 & -0.875 & 0.261 \\
\hline Brood stage II & - & - & - & - & 0.246 & 0.324 \\
\hline Brood stage III & - & - & - & - & -0.186 & 0.341 \\
\hline Weather & 0.173 & 0.094 & - & - & 0.131 & 0.099 \\
\hline Brood size & 0.317 & 0.118 & 0.310 & 0.116 & 0.295 & 0.119 \\
\hline $\operatorname{Sex}^{\mathrm{a}} \times$ Brood stage II & - & - & - & - & - & - \\
\hline Sex $^{\mathrm{a}} \times$ Brood stage III & - & - & - & - & - & - \\
\hline \multicolumn{7}{|l|}{ Biomass delivered } \\
\hline \multicolumn{7}{|l|}{ Model selection criteria } \\
\hline$\triangle \mathrm{AICc}$ & 0.00 & - & 2.03 & - & 4.85 & - \\
\hline $\mathrm{AICcw}$ & 0.66 & - & 0.24 & - & 0.06 & - \\
\hline Deviance & 312.96 & - & 310.55 & - & 308.81 & - \\
\hline \multicolumn{7}{|l|}{ Effects } \\
\hline Intercept & 0.264 & 0.159 & 0.402 & 0.184 & 0.311 & 0.199 \\
\hline $\operatorname{Sex}^{\mathrm{a}}$ & -0.545 & 0.112 & -0.545 & 0.111 & -0.363 & 0.192 \\
\hline Brood stage II & - & - & -0.108 & 0.137 & -0.013 & 0.191 \\
\hline Brood stage III & - & - & -0.219 & 0.140 & -0.038 & 0.196 \\
\hline Weather & 0.117 & 0.035 & 0.109 & 0.037 & 0.109 & 0.036 \\
\hline Brood size & 0.208 & 0.030 & 0.202 & 0.030 & 0.202 & 0.030 \\
\hline $\operatorname{Sex}^{\mathrm{a}} \times$ Brood stage II & - & - & - & - & -0.190 & 0.268 \\
\hline Sex $^{\mathrm{a}} \times$ Brood stage III & - & - & - & - & -0.362 & 0.274 \\
\hline \multicolumn{7}{|l|}{ Proportion of molecrickets in diet } \\
\hline \multicolumn{7}{|l|}{ Model selection criteria } \\
\hline$\triangle \mathrm{AICc}$ & 0.00 & - & 2.82 & - & 9.16 & - \\
\hline $\mathrm{AICcw}$ & 0.79 & - & 0.19 & - & 0.01 & - \\
\hline Deviance & 731.67 & - & 729.86 & - & 743.09 & - \\
\hline \multicolumn{7}{|l|}{ Effects } \\
\hline Intercept & 0.714 & 0.606 & 0.787 & 0.612 & 2.112 & 0.435 \\
\hline $\operatorname{Sex}^{\mathrm{a}}$ & -0.696 & 0.150 & -0.693 & 0.151 & -0.698 & 0.150 \\
\hline Brood stage II & -0.451 & 0.135 & -0.462 & 0.140 & -0.491 & 0.134 \\
\hline Brood stage III & -0.382 & 0.164 & -0.441 & 0.171 & -0.629 & 0.147 \\
\hline Weather & 0.210 & 0.034 & 0.214 & 0.066 & 0.188 & 0.034 \\
\hline Brood size & 0.289 & 0.085 & 0.274 & 0.086 & - & - \\
\hline Sex $^{\mathrm{a}} \times$ Brood stage II & -0.068 & 0.195 & -0.065 & 0.196 & -0.081 & 0.195 \\
\hline Sex $^{\mathrm{a}} \times$ Brood stage III & -1.217 & 0.227 & -1.218 & 0.227 & -1.133 & 0.225 \\
\hline Weather $\times$ Brood stage II & - & - & 0.056 & 0.092 & - & - \\
\hline Weather $\times$ Brood stage III & - & - & -0.058 & 0.085 & - & - \\
\hline
\end{tabular}

Only results of the best models are presented in the table. Given are the model selection criteria ( $\triangle$ AICc: difference in the small sample size adjusted Akaike's Information Criterion between the best and the current model; AICcw: Akaike weight; Deviance) and the effects

${ }^{a}$ Estimate for females 

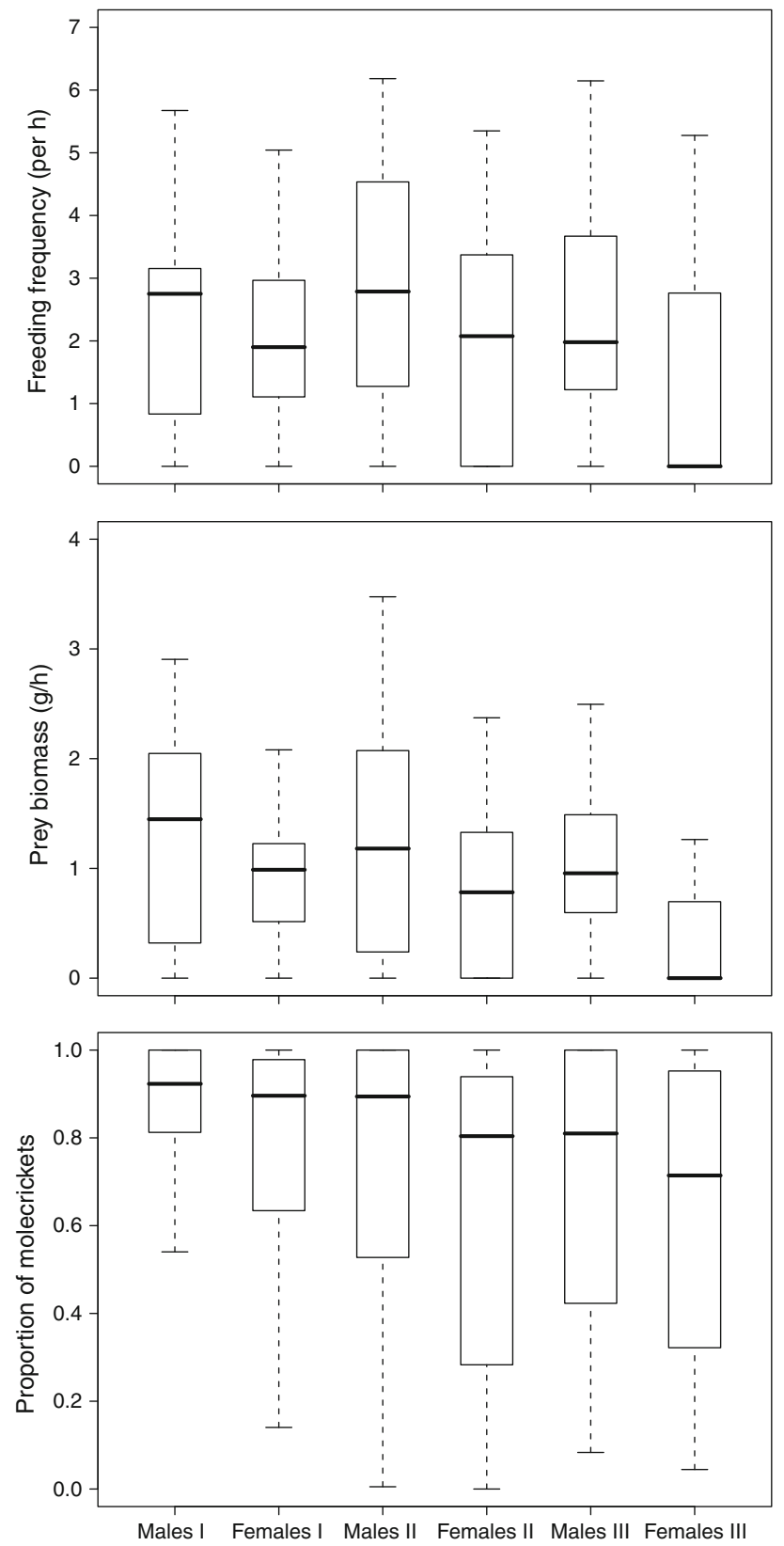

Fig. 3 Box plot of feeding frequency $(\mathrm{n} / \mathrm{h})$, prey biomass $(\mathrm{g})$ provisioned per hour and proportion of molecrickets derived at 26 Hoopoe breeding sites with respect to chick stage (I-III) and sex of parents

the most profitable prey, molecrickets (Fournier and Arlettaz 2001). This indicates that molecrickets are more difficult to find when the weather conditions are bad. Adults then switch to other prey types such as caterpillars (Fournier and Arlettaz 2001), yet, because these prey items are smaller, Hoopoes cannot fully compensate as they are single prey loaders. The low availability of molecrickets during bad weather must be due to reduced activity, detectability or accessibility at low temperature and during

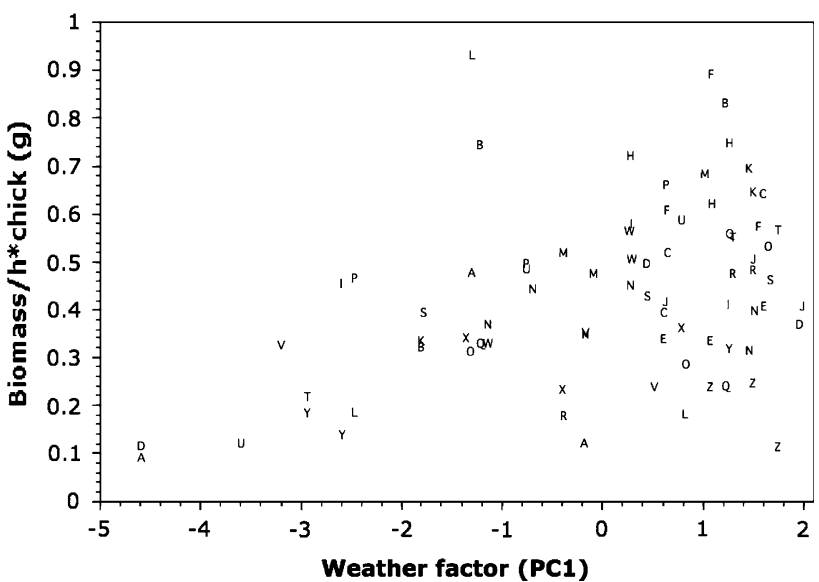

Fig. 4 Mean prey biomass provisioned per chick and hour (g) at 26 breeding sites in relation to weather factor. Each brood is depicted by a different letter (3 video filming sessions took place per brood, at stages I, II and III, respectively)

Table 2 Best three models out of 103 candidate models for reproductive output

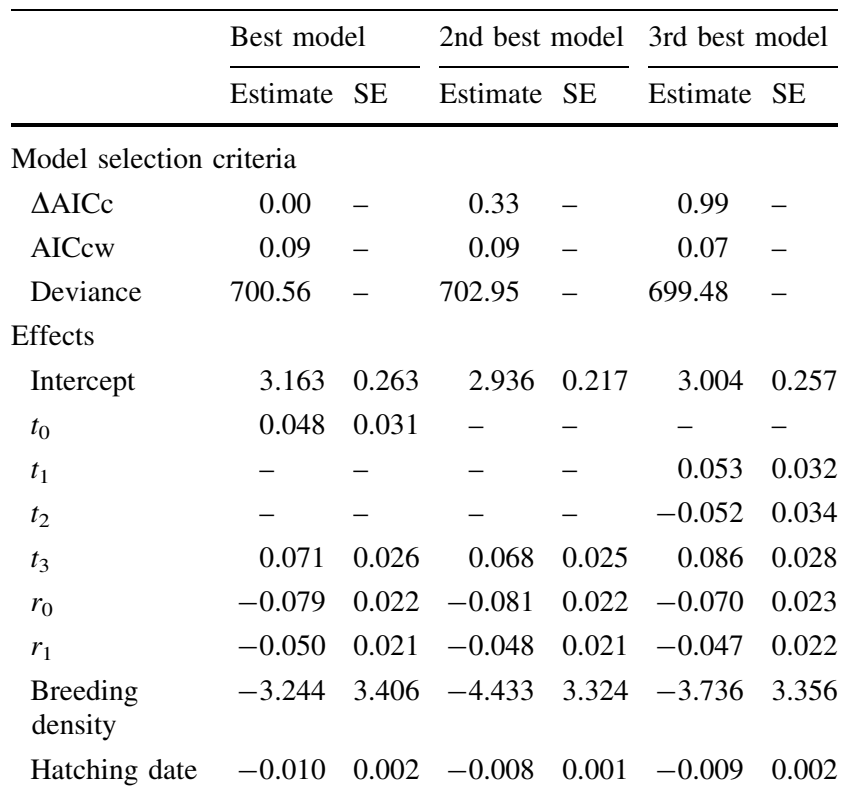

Model selection criteria $(\triangle \mathrm{AICc}$ : difference in the small sample size adjusted Akaike's Information Criterion between the best and the current model; AICcw: Akaike weight; Deviance) and the effects. See Fig. 4 for further details on model selection and "Methods" for the meaning of the variables

rainfall. It might well be that the terrestrial foraging habits of Hoopoes render them more susceptible to adverse weather than non-terrestrial insectivorous birds, which were the focus of the majority of previous studies on the impact of weather on reproduction in insectivorous birds (e.g. Cucco and Malacarne 1996b; Pellantova 1981; Veistola et al. 1997; Radford et al. 2001). 
Fig. 5 Reproductive output predictions for best model. Number of fledglings in relation to parameters in best model, means $\pm \mathrm{SE}$ of 1,000 bootstrap iterations
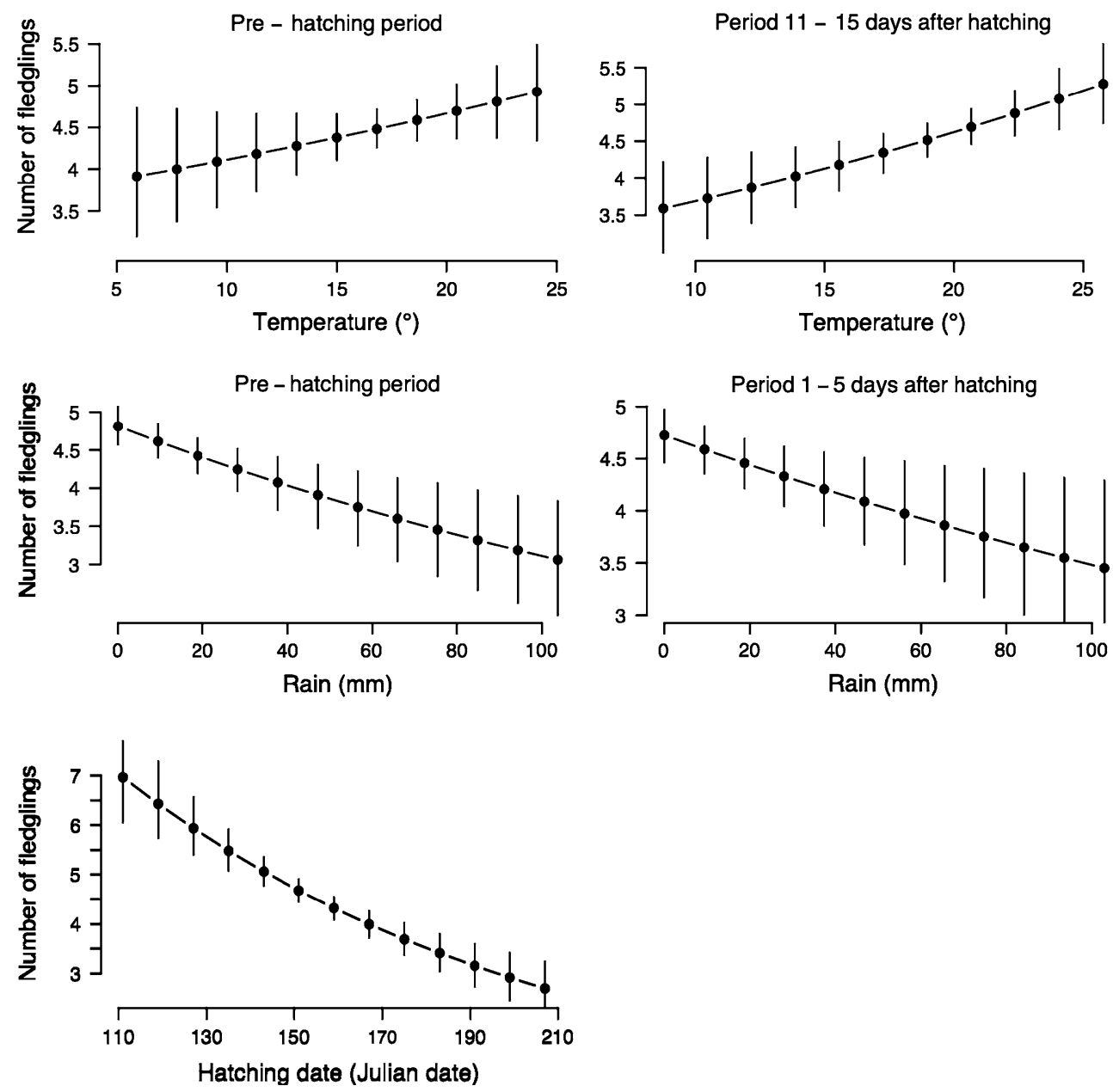

Feeding rate did not vary notably between the three chick stages, but there was some evidence that the biomass supplied decreased as chick age advanced. As we filmed nestlings only from age 11 days onwards, i.e. after $35-45 \%$ of the duration of chick stay at nest had elapsed, we have no quantitative data about the earlier feeding patterns. However, as the female covers the young until they thermoregulate by themselves (until about 8-10 days of age), our brood stage I actually corresponds to a burst of provisioning activity, which also matches the period when chick growth rate is maximum (Fournier and Arlettaz 2001) and, incidentally, chick mortality highest (unpublished data). A progressive decrease in food provisioning before asymptotic growth is common in birds (e.g. Turner 1983).

Male investment in food provisioning during chick rearing, counted as either number of prey items or biomass, was higher than that of the female in all stages. Moreover, Hoopoe males have to feed their partner during incubation and then contribute to the entire prey supply during early chick stages when the female still broods. Males and females thus differ markedly in their parental tasks: incubation relies totally on the female, whereas chick rearing is primarily the male's responsibility. We predict that male provisioning efficiency correlates with territory quality (i.e. molecricket availability at the study site), the acquisition of which will depend on male hierarchical status (Martín-Vivaldi et al. 1999). The drop in feeding effort by females in later stages may also be due to the fact that a large proportion of them leave their brood before the young have fledged, in order to engage into a new breeding trial, often with a different male to the previous partner (own unpublished data).

Our data on food provisioning by parents, combined with the modelling of weather factors, suggests that a reduced amount of delivered biomass (especially molecrickets) in bad years greatly affects productivity. Adverse weather, especially it seems around hatching time, impacted upon both survival and productivity, whilst warm, sunny and dry weather before hatching and during the last nesting phases boosted productivity. Yet, because ambient temperature, contrary to rainfall, correlated across pentades, we must interpret with caution the apparent impact of this factor during some specific phases of 
Table 3 Best three models out of 59 candidate models for nestling survival

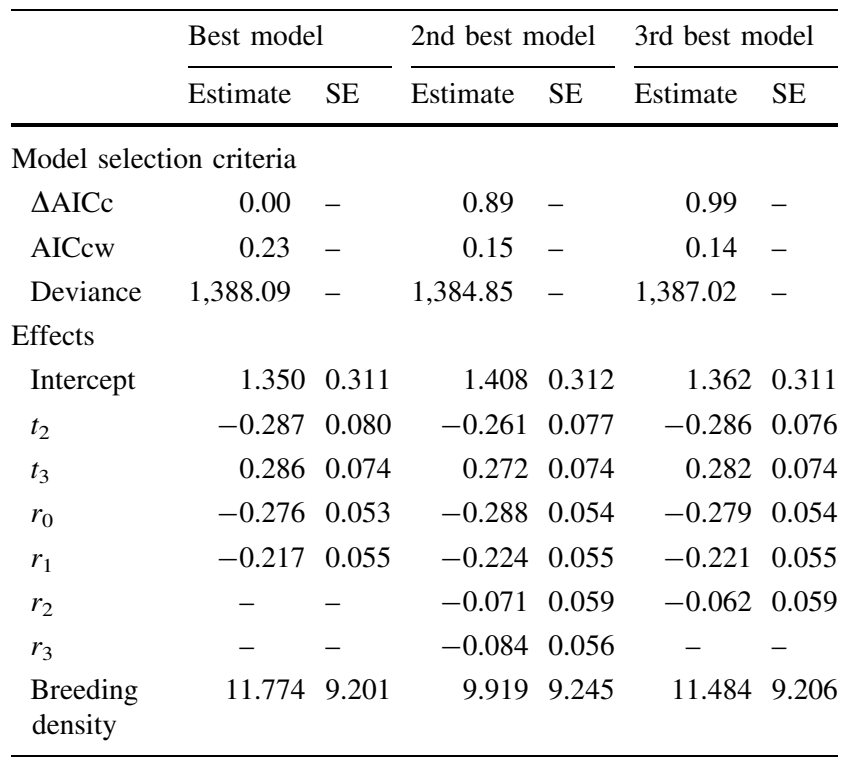

Model selection criteria $(\triangle \mathrm{AICc}$ : difference in the small sample size adjusted Akaike's Information Criterion between the best and the current model; AICcw: Akaike weight; Deviance) and the effects. See Fig. 1 for further details on model selection and "Methods" for the meaning of the variables

reproduction. An overall effect of temperature remains indisputable, however. The sensitivity of Hoopoes to limited food availability has been discussed by Martín-Vivaldi et al. (1999) in relation to the brood reduction hypothesis. These authors established that Hoopoes lay optimistic clutch sizes in order to raise as many chicks as possible. Parents appear not to feed smaller chicks as long as the larger ones are begging (Martín-Vivaldi et al. 1999), which biases mortality toward the youngest chicks. As less profitable prey is fed under unfavourable weather (this study), weather appears to be the ultimate factor responsible for a brood reduction strategy.

In general, population dynamics of short-lived species like that of Hoopoes is highly reactive to variations in factors regulating reproductive output (Sæther and Bakke 2000). Yearly adult survival is only around $40 \%$ (Reichlin et al., in review). Broods laid early in the season frequently produce $8-9$ young ( 7.8 and $2.1 \%$ of all 514 broods, respectively) in Valais (Fig. 5 bottom), with the fittest adults even capable of undertaking three broods a year. Hoopoe demography therefore reacts extremely sensitively to environmental change in the breeding area. Thus, we believe that the fluctuations and patterns of range extension/retraction reported for western, central and northern European Hoopoe populations during the twentieth century may actually have been caused by periodic climatic cycles, e.g. series of good or bad years in a row (Glutz von Blotzheim and Bauer 1980; Cramp 1985; Rehsteiner 1996).
This study also provides some support to the long-term predictive model of range shift by Huntley et al. (2008).

Any future Hoopoe conservation programme in western and central Europe should bear this weather issue in mind, especially in small peripheral populations. Of course, nestling survival and number of fledglings are two among several vital parameters potentially affected by weather variation. It is, for instance, likely that post-fledging survival is also affected by weather circumstances. Future population dynamics modelling based on extensive capture-recapture data may contribute to unravelling the relationship between post-nesting survival and weather conditions.

Sensitivity to weather and climate variation, as illustrated here, could be a serious impediment to the protection of peripheral, endangered animal populations (Lesica and Allendorf 1995). It might indeed annihilate costly local conservation efforts. One may expect this problem to become more acute in the face of continuing habitat fragmentation and climate change. The direction of these changes remains difficult to predict with accuracy, due for example to the subtle interplay between temperature and precipitation variation (Wanner et al. 1997). Most current climate scenarios, however, foresee an augmentation of extreme weather events, i.e. greater variability of local climate can be anticipated (Easterling et al. 2000). This may only further exacerbate the impact of environmental stochasticity upon population demographic trajectories and even mask the long-term, gradual changes caused by global warming in terms of range shifts (Huntley et al. 2008). This problem should be accounted for in any species conservation scheme, especially of small, peripheral populations.

\section{Zusammenfassung}

Einfluss von Wetter und Klimaschwankungen auf die Fortpflanzungsökologie und das Populationswachstum beim Wiedehopf

Die Erhaltung peripherer Populationen ist von zentraler naturschutzbiologischer Bedeutung, weil diese oft ein grosses Anpassungspotential an veränderliche Umweltbedingungen aufweisen. Solche Populationen sind hingegen oft klein und isoliert, wodurch sie auch sehr empfindlich gegenüber Zufallsereignissen und dadurch einem erhöhten Aussterberisiko ausgesetzt sind. In einem Tal in den Schweizer Alpen erforschten wir verschiedene Parameter einer peripheren Population von Wiedehopfen (Upupa epops), eine seltene, Insekten fressende Vogelart des Kulturlandes. Dabei untersuchten wir den Einfluss des Wetters auf die Fütterungsfrequenz der Altvögel und auf den Bruterfolg, unter Berücksichtigung der Siedlungsdichte. 
Daraus leiteten wir den Einfluss klimatischer Ereignisse auf die Populationsentwicklung ab. Die Fütterungsfrequenz und die verfütterte Biomasse waren bei schlechtem Wetter (kalte und regenreiche Tage) im Vergleich zu schönen Tagen reduziert und nahmen mit der Brutgrösse zu. Zudem fütterten Männchen mehr und öfter als Weibchen. An Tagen mit schlechtem Wetter wurden, unabhängig von der Brutgrösse, anteilmässig deutlich weniger Maulwurfsgrillen (Gryllotalpa gryllotalpa) herbeigeschafft. Diese energiereichen Beutetiere machen im Schnitt 93\% des Gewichts der verfütterten Nahrung aus. Niederschläge vor dem Schlüpfen und während der ersten Lebenstage hatten einen negativen Einfluss auf die Überlebensrate der Küken, wohingegen warme Temperaturen kurz vor dem Schlüpfen die Überlebensrate positiv beeinflussten. Die Anzahl flügger Küken ist negativ mit der Stärke der Niederschläge während des Schlüpfens korreliert, erhöhte Temperaturen während des Schlüpfens und kurz vor dem Ausfliegen wirkten sich positiv auf die Anzahl flügger Küken aus. Mit unseren Modellen konnten wir zeigen, dass Schwankungen bei der Zahl der Flügglinge einen grossen Einfluss auf die Wachstumsrate der Population haben. Wiederholtes Auftreten ungünstiger und regenreicher Wetterperioden im Frühling könnte die Population deshalb schnell dezimieren. Diese Fallstudie zeigt, dass Erfolge bei der Erhaltung peripherer Vogelpopulationen durch negative Einflüsse aufgrund klimatischer Bedingungen zunichte gemacht werden könnten. Bei der Ausarbeitung von Massnahmen in der Artenförderung muss demnach auch der Einfluss von Wetter und Klimaschwankungen auf die Arten berücksichtigt werden.

Acknowledgments We thank A. Sierro, P. Mosimann-Kampe, F. Leippert, H. Alber, M. Bendel, J. Fournier, A. Tagmann-Ioset, S. Mettaz, B. Posse, H. Routti, B. Tschirren, A. Valsangiacomo and N. Weisshaupt for their assistance. O. Roth and M. Whyte assisted with editing.

\section{References}

Antonovics J, McKane AJ, Newman TJ (2006) Spatiotemporal dynamics in marginal populations. Am Nat 167:16-27

Arlettaz R (1984) Ecologie d'une population de huppes, Upupa e. epops, en Valais: répartition spatiale, biotopes et sites de nidification. Nos Oiseaux 37:197-222

Arlettaz R, Perrin N (1995) The trophic niches of sympatric sibling Myotis myotis and Myotis blythii: do mouse-eared bats select prey? Symp Zool Soc Lond 67:361-376

Arlettaz R, Fournier J, Zbinden N (2000) Evolution démographique (1979-1998) d'une population témoin de huppe fasciée Upupa epops en Valais et stratégie de conservation ciblée. Nos Oiseaux 47:19-27

Arlettaz R, Christe P, Lugon A, Perrin N, Vogel P (2001) Food availability dictates the timing of parturition in insectivorous mouse-eared bats. Oikos 95:105-111
Avery MI, Krebs JR (1984) Temperature and foraging success of great tits Parus major hunting for spiders. Ibis 126:33-38

Burnham KP, Anderson DR (2002) Model selection and multimodel inference: a practical information-theoretic approach. Springer, New York

Bussmann J (1950) Zur Brutbiologie des Wiedehopfes (Upupa epops). Ornithol Beob 47:141-151

Cassel-Lundhagen A, Tammaru T, Winding JJ, Ryrholm N, Nylin S (2009) Are peripheral populations special? Congruent patterns in two butterfly species. Ecography 32:591-600

Channell R, Lomolino MV (2000) Dynamic biogeography and conservation of endangered species. Nature 403:84-86

Cramp S (1985) Birds of the western Palearctic, vol IV. Oxford University Press, Oxford

Crandall KA, Bininda-Emonds ORP, Mace GM, Wayne RK (2000) Considering evolutionary processes in conservation biology. Trends Ecol Evol 15:290-295

Crick HQP, Gibbons DW, Magrath RD (1993) Seasonal changes in clutch size in British birds. J Anim Ecol 62:263-273

Cucco M, Malacarne G (1996a) Reproduction of the pallid swift (Apus pallidus) in relation to weather and aerial insect abundance. Ital J Zool 63:247-253

Cucco M, Malacarne G (1996b) Effect of food availability on nestling growth and fledging success in manipulated pallid swift broods. J Zool 240:141-151

Easterling DR, Meehl GA, Parmesan C, Changnon SA, Karl TR, Mearns LO (2000) Climate extremes: observations, modeling and impacts. Science 289:2068-2074

Fournier J, Arlettaz R (2001) Food provision to nestlings in the hoopoe Upupa epops: implications for the conservation of a small endangered population in the Swiss Alps. Ibis 143:2-10

Geiser S, Arlettaz R, Schaub M (2008) Impact of weather variation on feeding behaviour, nestling growth and brood survival in wrynecks Jynx torquilla. J Ornithol 149:597-606

Gibson SY, Van der Marel RC, Starzomsi BM (2009) Climate change and conservation of leading-edge peripheral populations. Cons Biol 23:1369-1373

Glutz von Blotzheim UN, Bauer KM (1980) Upupa epops Linnaeus 1758-Wiedehopf. In: Glutz von Blotzheim UN (ed) Handbuch der Vögel Mitteleuropas, Band 9: Columbiformes-Piciformes. Akademische Verlagsgesellschaft, Wiesbaden, pp 852-876

Hendry AP, Kinnison MT (1999) Perspective: the pace of modern life: measuring rates of contemporary microevolution. Evolution 53:1637-1653

Hoffmann AA, Blows MW (1994) Species borders: ecological and evolutionary perspectives. Trends Ecol Evol 9:223-227

Horton P, Schaefli B, Mezghani A, Hingray B, Musy A (2006) Assessment of climate-change impacts on alpine discharge regimes with climate model uncertainty. Hydrol Process 20:2091-2109

Huntley B, Collingham YC, Willis SG, Green RE (2008) Potential impacts of climatic change on European breeding birds. PLoS ONE 3:e1439. doi:10.1371/journal.pone.0001439

Hustings F (1997) Upupa epops, Hoopoe. In: Hagemeijer WJM, Blair MJ (eds) The EBCC Atlas of European breeding birds: their distribution and abundance. Poyser, London, pp 438-439

Keller V, Zbinden N, Schmid H, Volet B (2001) Rote Liste der gefährdeten Brutvogelarten der Schweiz, BUWAL-Reihe Vollzug Umwelt. Bundesamt für Umwelt, Wald und Landschaft and Schweizerische Vogelwarte Sempach, Bern

Laiolo P, Bignal EM, Patterson IJ (1998) The dynamics of parental care in choughs (Pyrrhocorax pyrrhocorax). J Ornithol 139:297305

Lawton JH (1993) Range, population abundance and conservation. Trends Ecol Evol 8:409-413 
Lesica P, Allendorf FW (1995) When are peripheral populations valuable for conservation? Conserv Biol 9:753-760

Lomolino MV, Channell R (1995) Splendid isolation: patterns of geographic range collapse in endangered mammals. J Mammal 76:335-347

Martín-Vivaldi M, Palomino JJ, Soler M, Soler JJ (1999) Determinants of reproductive success in the hoopoe Upupa epops, a hole-nesting non-passerine bird with asynchronous hatching. Bird Study 46:205-216

Mills JA, Yarrall JW, Bradford-Grieve JM, Uddstrom MJ, Renwick JA, Merilä J (2008) The impact of climate fluctuation on food availability and reproductive performance of the planktivorous red-billed gull Larus novaehollandiae scopulinus. J Anim Ecol 77:1129-1142

Nantel P, Gagnon D (1999) Variability in the dynamics of northern peripheral versus southern populations of two clonal plant species, Helianthus divaricatus and Rhus aromatica. J Ecol $87: 748-760$

Nathan R, Safriel UN, Shirihai H (1996) Extinction and vulnerability to extinction at distribution peripheries: an analysis of the Israeli breeding avifauna. Isr J Zool 42:361-383

Newton I (1998) Population limitation in birds. Academic, San Diego

Parmesan C, Yohe G (2003) A globally coherent fingerprint of climate change impacts across natural systems. Nature 421:3742

Pellantova J (1981) The growth of young of the swift, Apus apus, in relation to the number of nestlings, temperature, feeding frequency and quantity of food. Folia Zool 30:59-73

R Development Core Team (2008) R: a language and environment for statistical computing. R Foundation for Statistical Computing, Vienna

Radford AN, Du Plessis MA (2003) The importance of rainfall to a cavity-nesting species. Ibis 145:692-694

Radford AN, McCleery RH, Woodburn RJW, Morecroft MD (2001) Activity patterns of parent great tits Parus major feeding their young during rainfall. Bird Study 48:214-220

Rehsteiner U (1996) Siedlungsdichte und Habitatansprüche des Wiedehopfs Upupa epops in Extremadura (Spanien). Ornithol Beob 93:277-287
Reznick DN, Shaw FH, Rodd FH, Shaw RG (1997) Evaluation of the rate of evolution in natural populations of guppies (Poecilia reticulata). Science 275:1934-1937

Rodríguez C, Bustamante J (2003) The effect of weather on lesser kestrel breeding success: can climate change explain historical population declines? J Anim Ecol 72:793-810

Sæther BE, Bakke Ø (2000) Avian life history variation and contribution of demographic traits to the population growth rate. Ecology 81:642-653

Sagarin RD, Gaines SD (2002) The 'abundant centre' distribution: to what extent is it a biogeographical rule? Ecol Lett 5:137-147

Sala OE, Chapin FS III, Armesto JJ, Berlow E, Bloomfield J, Dirzo R, Huber-Sanwald E, Huenneke LF, Jackson RB, Kinzig A, Leemans R, Lodge DM, Mooney HA, Oesterheld M, Poff NL, Sykes MT, Walker BH, Walker M, Wall DH (2000) Global biodiversity scenarios for the year 2100. Science 287:1770-1774

Schaub M (1996) Jagdverhalten und Zeitbudget von Rotkopfwürgern Lanius senator in der Nordwestschweiz. J Ornithol 137:213-227

Siikamäki P (1996) Nestling growth and mortality of pied flycatchers Ficedula hypoleuca in relation to weather and breeding effort. Ibis 138:471-478

Taylor LR (1963) Analysis of the effect of temperature on insects in flight. J Anim Ecol 32:99-117

Thomas CD, Cameron A, Green RE, Bakkenes M, Beaumont LJ, Collingham YC, Erasmus BFN, de Siqueira MF, Grainger A, Hannah L, Hughes L, Huntley B, van Jaarsveld AS, Midgley GF, Miles L, Ortega-Huerta MA, Peterson AT, Phillips OL, Williams SE (2004) Extinction risk from climate change. Nature 427:145148

Turner AK (1983) Time and energy constraints on the brood size of swallows, Hirundo rustica, and sand martins, Riparia riparia. Oecologia 59:331-338

Veistola S, Lehikoinen E, Eeva T (1997) Weather and breeding success at high latitudes - the pied flycatcher Ficedula hypoleu$c a$ and the Siberian tit Parus cinctus. Ornis Fenn 74:89-98

Wanner J, Rickli R, Salvisberg E, Schmutz C, Schüepp M (1997) Global climate change and variability and its influence on Alpine climate-concepts and observations. Theor Appl Climatol $58: 221-243$ 